\title{
NATO Enlargement and Albania's Path towards the Atlantic Alliance
}

\author{
Dr. Sokol Pacukaj \\ Aleksander Moisiu University, Durres Albania \\ Email: sokolpacukaj@uamd.edu.al
}

\section{Doi:10.5901/ajis.2013.v2n2p423}

\begin{abstract}
Albania was one of the first countries in Central and Eastern Europe to make its application for entry into NATO after the fall of communism in the region in 1989-1991. So, as for the other Western Balkan countries: such as Croatia or Macedonia Also Albania's application was evaluated by the Atlantic Alliance based on some criteria,: such as the state of Political and Economic Reforms, public opinion about the membership, Reforms on defense, the ability to Contribute to the missions of the Allies, the role of Albania in the region. Criteria for a young democracy: such as the Albanian were all to meet. However, according to Functional many observers, the NATO decision on Albania's application was blackberries political Judgment on the part of NATO member countries based on the repute the accession of the Balkan state would contribute to regional security rather than on the satisfaction of all criteria Imposed by NATO before accession.
\end{abstract}

Keywords: NATO, Albania, Western Balkan, Regional cooperation, Security.

\section{Introduction}

The main challenges of the Albanian application to NATO according to international observers were mainly issues concerning its political reforms. The Albanian President Alfred Moisiu in 2004 wrote that "... the public and political perception for the Alliance is a key step towards the development of a system with stable democracy and a functioning market economy, "showing that the integration would bring stability not only in Albania but the whole region. At the same time, the Chief of the Albanian State has admitted that his country did not expect to receive an invitation as a sort of loyalty bonus or an act of charity. In this regard Moisiu declare

\begin{abstract}
"Albania will not be invited to join NATO simply because of the high level of public support or for the contribution it has made in the peace missions of NATO. ... But the invitation will be the recognition of the hard work and the successful conclusion of a long and comprehensive reform process in bringing the standard to those of the Alliance. The country is determined to work to meet the criteria for membership of NATO in particular the military. "(NATO Review, Spring 2004)
\end{abstract}

Albania today is led by a center-right government where the Democratic Party headed by its historic leader Sali Berisha, in coalition with other smaller parties, which has been in office since 2005. Berisha in the past has often been criticized for his hard and uncompromising leadership style though his politics in recent years, especially after the 2005 elections and after his re-election in 2009 demonstrated political maturity and sense of responsibility towards the country. Strong points in its favor are the strong economic growth of recent years, the visa liberalization with the European Union and the country's entry into NATO. From the first multiparty elections in 1991, the Albanian politics has often been characterized by political conflicts between parties and factional struggles within them. In the first term as Prime Minister for Berisha, public order collapsed completely for several months in 1997 after the failure of financial pyramid. The two main political forces of the country Berisha's Democratic Party and the Socialist Party of Fatos Nano before and after Edi Rama, every time they lost the elections have never admitted defeat, accusing the winner of fraud and irregularities. The political situation has always been concerned about Europe and the U.S. and the two key issues that have always been 
mentioned by them but also by NATO and the Albanian leaders themselves have been electoral and judicial reform ${ }^{1}$. The Albanian Parliament passed new laws regarding these two important aspects often but progress has been slow and electoral reform is still one of the main demands of the Albanian opposition.

In any case, the adherence of' Albania to NATO is a unique story of a special relationship. This becomes obvious when one considers that there is no country of the 'Alliance in which public consensus regarding the entry into the North Atlantic Treaty exceed 96 percent of the vote.

In addition, the history, the people, the culture and the geo-strategic position of Albania offer the 'image of a particular country that, from a political and institutional instability that characterized it in the early nineties, has now become a guarantee of security able to contribute worldwide in major peacekeeping operations of NATO and of European Union.

Like many nations in the world, Albania has experienced a profound transformation in recent years as it played a crucial role in supporting the operations of the Allies to end the humanitarian tragedy in Kosovo and to ensure peace in the region.

Albania has undergone a unique insulation in the world and put an end to over 40 years of communist rule in 1991. After the collapse of communism, it has established a democratic regime of Western values and freedoms and has now a common heritage of a country ready to resume its role in the international community.

Despite the dramatic events that have hit the western Balkans in the nineties, democracy in Albania has strengthened its roots and has grown rapidly, surpassing even some "youthful errors"2.

The analysis of the Albanian community outlines another peculiar aspect of this country. In fact, Albania is the only country in the world whose boundaries are surrounded from a population that shares the same nationality (from a 6.5 only 3.6 million Albanians live in their country). This peculiarity gives Albania a key role in the geopolitics of the region and more responsibility for stabilization and the Euro-Atlantic integration of the Western Balkans.

An important role in Albania also had religious freedom and the excellent relations between the faiths in the country. Unlike other tragic experiences connected with religion, the Albanian culture has always been open to other cultures and different religious affiliations, which was never considered as a threat or as a factor of division. The Albanian people also, had always been oriented towards the West while preserving its culture but enriching it with new Western values. The satellite antennas in all Albanian cities testify to the desire for a free and pluralistic information of the Albanian citizens that the early nineties supported the process of European and Atlantic integration. Remember that among the first slogan of the demonstrators who were protesting against the communist regime in the streets there was also "We want Albania like the rest of Europe." The desire for integration is so strong that support for integration policies is ensured by the vast majority of public opinion in Albania.

\section{The Bucharest Summit Declaration}

The Bucharest Summit Declaration adopted by the Heads of State Governments on the $3^{\text {rd }}$ of April 2008, which called on Albania and Croatia to be part of the Atlantic Alliance has definitely marked the beginning of a new chapter for the Western Balkans shows when way toward a future in which a stable region fully integrated in Euro-Atlantic institutions would be able to make an important contribution to international security. In this perspective, the role of Albania in the region is crucial.

As has been said, between countries of the ex-Soviet bloc, Albania was the first to look for the NATO membership. From the moment the country joined Cooperation to the Council of the North Atlantic (North Atlantic Cooperation Council) in 1992, renamed Council of the Euro-Atlantic in 1997, (Euro-Atlantic Partnership Council), the Euro-Atlantic integration has always been one of the main objectives of all Albanian governments and political parties, helped by strong public consensus in Albania.

\footnotetext{
1 "Further Reform Necessary in Albania", parole del Secretario Generale della Nato Jaap de Hoop Scheffer, nel incontro al quartier generale della Nato il 19 Ottobre, 2007, in http://www.nato.int.

2 "Albania and NATO: Achievements and Perspectives" Speech by the Secretary General of the Italian Atlantic Committee, Fabrizio W. Luciolli, at the 13th International Conference of the Albanian Atlantic Council, that it s time to Tirana March 20, 2009 in www.comitatoatlantico.it
} 
Looking back, the path towards Albania's NATO membership seems impressive: after accession to the Council of Cooperation in 1992, Albania has expanded its relations with NATO in 1994 to join the Partnership for Peace (Partnership for Peace, PfP), and during and the same year was established at the Atlantic Council of Albania (Atlantic Council of Albania, ACA), which brought together the best representatives in the political, diplomatic, military, academic and economic level. The Board of ACA was important for the number record of initiatives and conducted its inception up to the full membership of Alliance. Notwithstanding the difficulties of national and regional activities of the ACA has been of crucial importance in the international community in promoting the vision and aspirations of the Albanian Euro-Atlantic structures.

In 1995, Albania has developed the first Individual Partnership Program (Individual Partnership Program, IPP) and in 1996 the country became a part of the process and vision (Planning and Review Process, PARP). In the same year, the Albanians have joined forces under the leadership of NATO as peacekeepers in the SFOR mission in Bosnia and Herzegovina.

Albania has also had a crucial role in supporting the mission of the Allies to end the humanitarian tragedy in Kosovo and in contributing to the stability of the region after the NATO air campaign air against Serbia.

\section{The Washington Summit and the Membership Action Plan (MAP)}

At the Washington Summit in April 1999, Albania joined the Membership Action Plan (MAP) and has become an aspiring member of NATO, along with Croatia and FYROM Macedonia.

After the Washington Summit Albania has been engaged in many NATO missions including missions in Iraq and Afghanistan and in April 2008 NATO Heads of State and Government meeting in Bucharest, they called on Albania's lawyer to talk membership with the Alliance. Allies signed the Protocol of Accession of Albania to the North Atlantic Treaty on $9^{\text {th }}$ of July 2008. Some time later the ratification process in the member countries of NATO. Ratification of the Italian Parliament was on $22^{\text {nd }}$ of December 2008. On April $4^{\text {th }}, 2009$ Albania became a full member of NATO.

The objectives and the requirements of the MAP were concentrated in five main areas: policy, economic defense, finance, and legislation and information security. These requirements together with objectives of Partnership for Peace to be realized in the framework of the PfP and PARP have called for a thorough reform of the armed forces but not only Albanians but also of all the institutions of the country. The Membership Action Plan has been a key tool not only for Albania but also for other countries that want to be NATO members. The MAP allows countries to benefit from the support of the Alliance in complete reforms in key areas, to stay abreast of reforms that NATO requires and to ensure that countries are able to make a significant contribution to the Alliance, once the accession process will be concluded.

The Albanian Armed Forces have showed a long-term development plan (2000-2020) with the aim of achieving a modern armed force, motivated and professional.

Thanks to this and transformation, the Albanian Armed Forces are today contributing in all major peacekeeping operations, NATO and the EU around the world.

The accession of Albania into NATO went in parallel and has been integrated with the country's efforts to adhere to the European Union. At present, Albania is officially indeed "potential candidate" country for European Union and since 2007, it signed the Instrument of Pre-Accession (IPA). The next appointment with the European Union for the Albanian government will be at the end of 2011 when the Union will be speaking about the Albanian request to become a "candidate country". Because of the tense political situation where the opposition Socialists Edi Rama refused to accept the result of the general elections of 2009 also boycotting the Parliament sessions, the Union has refused the request of a candidate country of Albania presented in April of 2011. Difficulties presented on the outcome of the second attempt of the Albanian government led by Sali Berisha in Brussels. The normal functioning of institutions is one of the cornerstones of the Union, while still the leader and former mayor of Tirana Edi Rama refuses cooperation with the majority of Berisha. In September of 2011 Rama decided to stop the boycott of parliamentary sessions but did not accept the EU's conditions for a qualified majority vote for the laws that guarantee the necessary reforms that the country needs and that are required by the European summits. The road to the EU is complicated but the Albanian Prime Minister is confident that sooner or later will find an agreement with the opposition in the common interest of the country. A good compromise might be the place of the President of the opposition in return for voting for the reforms required by the EU. The Albanian politics should prove to be more mature and inclined to dialogue inside. To determine if the request of Albania has a positive, it needs only to wait until the end of 2011. The road towards European integration is the only one for the country and whether Albania will meet the standards required the doors to Europe will open. Conversely, if the political situation in 
Albania did not change or even worse does not only mean that NATO membership is only served to the legitimacy of the political class, but also that Albania is still in a fragile democracy despite the great progress that the country has made in recent years.

\section{The Role of Euro-Atlantic integration}

In the path of Euro-Atlantic integration a special partner who has always supported Albania is definitely Italy.

In addition, Italy is the top trade partner, $35 \%$ of the Albanian trade as a mater of fact, takes place with Italy which by the way is also the first investor in terms of number of companies and the largest donor ${ }^{3}$. A strong support and contribution to the accession of Albania into NATO has also given the Italian Delegation of Experts (DIE). The DIE was established August 28 $8^{\text {th }}, 1997$, at the end of the Italian mission "Alba", in the context of Protocol of Understanding signed by the ministers of Defense of Italy and Albania. During its time, the DIE has conducted in Albania bilateral cooperation activities and provided support to the Albanian Armed Forces to adapt its structures to Born models, by means of conceptual, logistical and training aspects. To express gratitude to the work played by DIE, in 2006, the Albanian President Alfred Moisiu, on a proposal from the Minister of Defense, has decorated the General Gravante who led the DIE from 2004 to 2006 with a distinction: "For their valuable contribution to the process of modernization of the Armed Forces of the Republic of Albania", which was given to him by the Minister of Defense Fatmir Mediu.

The Italian Delegation testifies to the fruitful cooperation established in the military sector between the two countries. Moreover, the balance of trade between Albania and Italy increases steadily from year to year.

The accession of Albania has been made possible thanks to the country's efforts in taking the road of important reforms such as those policies especially on the reform of the electoral law, in the field of economic liberalization and favorable laws for the development of small and medium enterprise, and defense adjusting the Albanian army of Born models, all this in response to the changing security environment at the national and international level. As a functional democracy, Albania today is definitely a safer country, which can offer security to its citizens and ensure the stability of its neighbors, and not only.

The boats full of illegal immigrants coming from the Albanian coast are still etched in the collective imagination but today Albania is no longer the country of illegal immigration, trafficking in human beings and the fight against drugs, corruption and smuggling is bearing results. This goal is reached thanks to the actions taken over the years by governments of Albanian, through the consolidation of democratic institutions policies, the rule of law, the increase of internal security, customs and skills of effective control borders, particularly of maritime safety.

\section{The Albanian Armed Forces and the international and regional cooperation}

The Albanian Armed Forces have been a significant component of these Reform and being in constant progress towards a completely transformed military organization built on the functional standards of NATO, able to assume its responsibilities, both nationally and internationally, helping to a series of missions in NATO and in the EU such as those promoted in Bosnia and Herzegovina, Iraq, Chad and the most important in Afghanistan. ${ }^{4}$

NATO membership has meant that Albania has become part of a security organization today indispensable in the world and, at the same time, the Balkan country taking on new responsibilities; it can do its part in protecting the EuroAtlantic values.

Albania should consider its own safety as inseparable from the context of global security by participating in active way or international peace missions, with the objective to promote and ensure international security, peace and stability. Its participation in the missions is not only an obligation arising from the accession to NATO but also a common share of international security.

The process of NATO enlargement also shows how the values and security interests converge for all countries. Approximately the logic of integration through the NATO enlargement remains valid and is particularly useful in the

\footnotetext{
${ }^{3}$ For more detailed trade data refer to the website of the Institute for Foreign Trade www.ice.goc.al.

4 "The contribution of Albania to Atlantic security", Speech by the Minister of Defence of the Republic of Albania, Mr Arben the Imam, on the occasion of the conference: "Security and Cooperation in the Mediterranean" in Lucan, in www.comitatoatlantico. it
} 
Western Balkans where Euro-Atlantic integration offers the only viable road towards sustainable peace. Regional cooperation is a very important factor for the security and economic development in the Western Balkans.

Multilateral relations were in fact at the center of Albanian politics and materialized in verse regional initiatives. All inside of the current dynamics of the policy and security registered as one of South East Europe countries, Albania has played an active role and has participated in important initiatives such as SEDM, A3 and further to the Adriatic Charter 5, South Cooperation and Eastern Europe, the RACVIAC, Adriatic-Ionian Initiative etc.

One of the most significant experiences, from this point of view, it is definitely the Adriatic-Ionian Initiative (All). Launched in October of 1999 at the European summit in Tampere and formalized the following year, the Initiative associated with the states of the Adriatic and Ionian basin (Italy, Greece, Slovenia, Croatia, Bosnia, Albania, Serbia and Montenegro) and aims to set up and under on the aegis and macro level that enhances the cooperation between member countries. Operation that has a clear corollary: the normalization and integration of the Western Balkans to the EU.

The Western Balkan region is now in a time of substantial change, with significant security implications and the search for freedom, dignity, democracy and a sustainable economic development.

Albania has no outstanding territorial issues with its neighbors. It was one of the first countries to recognize Kosovo's independence when the former Serbian province declared independence on February $17^{\text {th }}, 2008$. This fact has increased the tensions in relations with Serbia, but Albanian leaders have repeatedly said that Albania has no intention to join with Kosovo or with the majority of ethnic Albanians in Macedonia for the creation of a "Greater Albania". In fact, both the U.S. and the EU have often praised for its location Albania mode installment on the issue of Kosovo.

The interdependence of the Western Balkans, can lead to a new dynamic development and indispensable for the European integration in the region that can not be achieved except through well-coordinated efforts of the countries of the region.

The Balkans and especially Albanian position have a strategic geographical position as a bridge between East and West. The acceleration of European integration in the entire Balkan region will bring greater security not only to the region but to the whole of Europe.

The region has moved from war to peace in the 1990s, from the disintegration of a development towards a sustainable future of Euro-Atlantic integration. This area of Europe 's who suffered the wars of ethnic rivalry, bloody hyper-nationalism, has turned into a region where they become crucial guiding principles of the Covenant, as the preamble of the North Atlantic Treaty signed in Washington on April $4^{\text {th }}, 1949$, according to which NATO member countries are "determined to safeguard the freedom of their people, their common heritage and civilization of their own, based on the principles of democracy, individual liberty and on the rule of law, anxious to promote in the region of North Atlantic wellbeing and stability, determined to unite their efforts for collective defense and for the maintenance of international peace and security.

Today, Albania is an active player in the region, and its position within the Alliance is consolidating. The ability to contribute to the preservation of peace and stability has meant those three years after NATO membership, Albania obtained a new status and a more important role in international relations. Moreover, the new status of NATO extraordinarily increases the geostrategic position of Albania, which is the gateway to the Balkans at the crossroads of the Mediterranean and the Caucasus who will ensure the energy of Europe.

The Albanian politics is conducive to regional cooperation and this is also seen in the words of the Albanian Defense Minister Arben Imami when he declares that,

\begin{abstract}
"Albania has clearly expressed its approval to the policy of "open doors", mainly because the complete integration of the Balkans in NATO and the European Union is the only way to ensure safety and economic prosperity throughout the region. In this regard, we strongly support the partnership and membership of Kosovo as a responsible initiative for all regional and international organizations.
\end{abstract}

Today, Kosovo is a new state, although still in the process of recognition by many states, but its independence has promoted and supported much of Europe and the United States. Kosovo can actively contribute to the safety and acceptability of the region. The role of NATO in Kosovo was very important for peace, stability and security of the country and the whole region but it is a fact that Albania gave a great help and has had a mediating role not only with regard to Kosovo, but this applies to the whole region. Its constructive approach is certainly to be commended for the fact that Albania is also looking beyond the region, participating in almost all missions including the latest NATO mission in Libya. 


\section{Conclusion}

All NATO member countries must now consult and coordinate on the strategic issues of the $21^{\text {st }}$ century. Challenges of the future must be seen together, even far from borders and challenges facing together by forming a strategic context so that no country can hope for an individualistic political policy but rather to create the conditions for which they cooperate with each other.

The full accession to the NATO mission of Albania marked results in a sense that this extraordinary young democracy has been able to reach it in difficult years as a result of a difficult process but coherent integration.

After the Summit in Strasbourg and Kehl on April $4^{\text {th }}, 2009$ when we celebrated the sixtieth anniversary of the signing of the Washington Treaty, it has opened a new phase for Albania's contribution to the euro-Atlantic institutions.

Albania calls or takes more responsibility in the stabilization of the Western Balkans and in their perspective of full integration in Euro-Atlantic institutions; also if there must be Albanians in Kosovo and Macedonia, which can play a crucial role in this regard.

After more then 20 years of transition of ups and downs, Albania is now a country with a mature democracy, ready to take on new responsibilities in the region and with the wider international security.

\section{References}

Beata Górka-Winter and Marek Madej, "NATO Member States and the New Strategic Concept: An Overview", The Polish Institute of International Affairs, Warsaw in May 2010.

R. Hendrickson, R. Smith, Croatia and NATO: Moving Toward Alliance Membership, Easten Illinois University, 2006.

Cepanec Z., Croatian membership in NATO: one of the crucial prerequisites for stabilization of Southeastern Europe, Monterey, California, March 2002.

Cepanec Z., Croatia and NATO: The Stony Road to Membership, Monterey, California, March 2002

Congressional Research Service, "NATO Enlargement: Albania, Croatia, and Possible Future Candidates" April 14, 2009.

The Centre for European Security Studies, The Western Balkan candidates for NATO membership and partnership, 2005.

Centre for European Security Studies, The Western Balkan candidates for NATO membership and partnerships, 2005

Pietz T., M. Remillard Defense conversion and reform in Albania, Macedonia and Croatia, Bonn International Center for Conversion, 2008.

Cepanec Z., Croatia and NATO: The Stony Road to Membership, Monterey, California, March 2002.

Stanicic M., Croatia and NATO in the Western Balkans Security Observer, No. 5, April-June 2007.

J. DeHart, The Burden of Strategy, Transatlantic realations and the future of NATO enlargement, Geoergetown University, 2008.

Levkovska L., The Limits of rhetorical entrapment: NATO enlargement in Southeast Europe, Centralk European University of Hungary, 2008.

Ryan C. Hendrickson, Jonathan Campbell and Nicholas Mullikin, "Albania and NATO's 'Open-Door' Policy: Alliance Enlargement and Military Transformation", in Journal of Slavic Military Studies.

Thomas S. Szayna, NATO Enlargement, 2000-2015 (Washington: RAND, 2000).

\section{Web sources}

www.aco.nato.int

www.acus.org

www.comitatoatlantico.it

www. eu-un.europa.eu

www.ice.goc.al

www.mod.gov.al

www.morh.hr

ww.nato.int

www.osservatoriobalcani.org 